\title{
Necessity of Legal Regulation on Non-marital Cohabitation
}

\author{
Lei Tan \\ School of Law, Humanities and Sociology \\ Wuhan University of Technology \\ Wuhan, China
}

\begin{abstract}
Unmarried cohabitation is a very common phenomenon, which is based on a certain social foundation. The interaction of economy, culture and system makes the spread of unmarried cohabitation irresistible. The convenience brought about by non-marital cohabitation is undeniable, but the identity and property problems caused by it also need to be solved urgently, and the problems caused by the lack of existing laws cannot be properly solved. Therefore, it is urgently needed to introduce a legal system related to nonmarital cohabitation, so as to solve a series of problems, stabilize the harmonious family relations and maintain the harmonious development of society.
\end{abstract}

Keywords-unmarried cohabitation; registered marriage; identity relationship; property relationship

\section{INTRODUCTION}

Since ancient times, unmarried cohabitation has been suppressed by society and prohibited by law for a long time. In recent years, the phenomenon of non-marital cohabitation has been increasing, which has become an unavoidable fact. Although China's law does not prohibit non-marital cohabitation, the relevant legislation tends to be blank. Many existing judicial interpretations are mainly focused on nonmarital cohabitation in accordance with the actual marital status, which has great limitations. This article tries to elaborate the necessity of regulating the phenomenon of unmarried cohabitation by law from the aspects of phenomenon, problems, legal status quo and advantages of legislative regulation.

\section{ThE CHANGE OF FAMILY MODEL}

\section{A. The Weakening of the Marriage System}

According to a report published by the Supreme People's Court, more than 140,000 divorce disputes were settled by the national courts in 2017, with a slight increase from 2016 (more than 1.12 million in 2014 and 1.2 million in 2015). Divorce disputes show an increasing trend year by year. Earlier, the Civil Affairs Bureau released statistics on social services in various provinces in the fourth quarter of 2018. Statistics show that the number of registered marriages in China in 2018 was 10.108 million, down $4.9 \%$ from the same period last year, and the number of registered divorces was 3.8 million. The number of marriages in 2018 has declined for the fifth consecutive year since 2013. Divorce cases also increase year by year, but the number of marriages decreases year by year, causing a panic to the society, that is, whether marriage is the best destination for two people's feelings? In this society where the divorce rate is increasing sharply, more and more people have hesitant attitudes towards marriage, even have feelings of exclusion. According to statistics, the stable duration of marriage has also dropped from seven years before to three to four years now. It can be said that marriage has greatly reduced the function of improving people's happy life.

\section{B. The Rise of Cohabitation Phenomenon}

Unlike the precarious status of the marriage system, cohabitation is an unstoppable global trend. The phenomenon of unmarried cohabitation has become very common among young, middle-aged and elderly people. Richard A. Posner, an American scholar, pointed out that "the divorce rate has risen sharply, accompanied by the substitution of cohabitation for marriage and the use of cohabitation as a pre-marital preparation." In 1983, more than $40 \%$ of all children born in Sweden were born out of wedlock. Some British scholars believe that unmarried cohabitation tends to spread in Europe and North America. In England, for example, in 1960-2000, the proportion of women aged 20-50 living together was three times as high. According to the 1997 Anthology of China Association for the Construction of Marriage and Family, in 1996 alone, nearly 200,000 people in the economically and culturally developed Guangdong Province failed to register for marriage, and in some areas the registration rate was only $60-70 \%$

\section{BASIS OF COHABITATION PHENOMENON}

\section{A. Economic Background}

In the final analysis, the change of family form is determined and restricted by the development level of material production and social and economic relations. That is to say, the development of family form is a historical category. As the center of society, the traditional marriage and family undertakes most of the social functions, such as economy, religion, education, entertainment and so on. In the past 30 years, with the reform and opening up in China, the development of economy and society has brought about 
significant changes in family functions: the production function has been lost to recovery; the reproductive function has been gradually degraded; the consumption function has changed from single to multiple; the support function has been weakened, and the educational function has been differentiated. For centuries, the division of labor and specialization within the family has greatly increased the productivity of couples, and marriage has guaranteed a higher level of production and consumption. These economic factors make the marriage system unstable. But the industrial revolution reduced the function of marriage, because the advanced science and technology after the revolution made many jobs no longer limited to men who had physical advantages, but let women come out of their families and take up positions. People increasingly resorted to forces outside the family in daily activities such as education, communication, production and relief. The gap between women's economic status and men's status is gradually narrowing, and women are no longer listening to men's words, but increasingly have their own opinions. Because they are no longer financially dependent on men's support, they have the right and ability to choose whether to marry or divorce. According to statistics in divorce cases, $73.4 \%$ of the cases plaintiffs are female. $77.51 \%$ of couples applied to the court for dissolution of marriage because of emotional discord, and $14.86 \%$ of couples applied to the court for dissolution of marriage because of domestic violence. It can be reflected that the rise of women's economic status supports their courage to refuse unhappy marriages. In essence, the rise of divorce rate is also a manifestation of the more equal status of men and women.

\section{B. Cultural Background}

Article 33 of the Fourth Amendment to the Constitution of China in 2004 stipulates that the state should respect and protect human rights. The importance of human rights has been enhanced unprecedentedly, and the "people-oriented" concept of marriage morality has replaced the "familybased" traditional concept of morality. "In modern society, individual's subjective right consciousness is increasingly strong in the social transformation, and individual's disposition of sex has become autonomous." Family-based family thought is impacted by the inviolability of individual rights. People no longer respect family supremacy, but rather choose different ways to pursue their own happiness. Especially the promotion of sexual individualism, with the development of social economy, the change of people's ideas, the gradual realization of equality between men and women, especially the separation of sex and fertility and the reduction of social control over sex. Traditionally considered sacred sexual relationships have changed more independently and tacitly. "It does not become sacred and noble because it wears the cloak of marriage, nor does it change lowly and insignificant because it lacks the shelter of marriage." After women and men have equal economic status, they no longer rely on "chastity" to obtain male support, but choose to live with each other for physiological and emotional needs. Cohabitation, as a highly similar way of family combination to marriage, has been favored by many people. People are no longer bound by discriminatory statements about non-marital cohabitation. If cohabitation is stable, they can also obtain the rights and interests provided by marital life. More importantly, they are free from a series of procedural problems to be satisfied by marriage. Therefore, for most people, cohabitation is not a discriminatory way. Therefore, why not choose unmarried cohabitation?

\section{The Concrete Reality of Choosing Unmarried Cohabitation}

1) The realistic basis of cohabitation of young people: Young people choose to live together without marriage mainly for three reasons: one is that they have to choose to live together because of their high marriage age. With the improvement of material living standards, the physical development of women and men has matured at the age of sixteen or seventeen. There is a physiological need for sexual life. With the opportunity of full contact with heterosexuals, love will naturally occur. With the maturity of physiology and emotion and the permission of social environment, sexual requirements will naturally arise. But before reaching the legal age of marriage, cohabitation is the only choice. The second is to regard cohabitation as a transitional stage of entering marriage, that is, trial marriage before marriage. In this case, most of the reasons for choosing cohabitation without direct marriage are fear of experiencing a failed marriage, not wanting to enter into marriage life rashly, and wanting to further understand each other through cohabitation, so as to decide whether to choose marriage or not. Thirdly, it is a simple mode of family integration that pursues a free way of life, that is, cohabitants live together in order to obtain all the conveniences of this family mode, rather than preparing for marriage.

2) The realistic basis of cohabitation of middle-aged and old people: The reason why middle-aged and old people choose to live together without marriage is mostly due to the family of both sides, so as to avoid the contradiction between the personal and property relations between children and cohabitants. Because both sides of non-marital cohabitation may have their own children, and if the middleaged and old people choose to marry, they will face the problem of property division between the two families. In this case, the middle-aged and old people will probably not choose marriage for the sake of their children, and some children are reluctant to bring about the problems of personal and property relations caused by parents' marriage.

\section{CuRrent Status OF LEGal REgulations ON UNMARRIED COHABITATION}

\section{A. Existing Laws}

First, with regard to the determination of non-marital cohabitation, the Supreme People's Court's interpretation of the application of the Marriage Law of the People's Republic of China (1): Article 5 stipulates that men and women who 
do not register for marriage and live together in the name of husband and wife in accordance with Article 8 of the Marriage Law shall be prosecuted in the People's Court for divorce and treated differently; (2) Marriage Registration of the Ministry of Civil Affairs on February 1, 1994: Before the promulgation and implementation of the Regulations, if both men and women have met the substantive requirements of marriage, they shall be dealt with in accordance with the factual marriage; (3) If, after the promulgation and implementation of the Regulations on Marriage Registration Administration of the Ministry of Civil Affairs on February 1, 1994, both men and women meet the substantive requirements of marriage, the people's court shall inform them to re-register the marriage before the case is accepted; if the marriage registration is not re-registered, the cohabitation relationship shall be handled. Secondly, with regard to the division of property in cohabitation, Article 15 stipulates that marriages declared null and void or annulled shall be dealt with jointly as the property acquired by the parties during their cohabitation, except where there is evidence that it is owned by one of the parties. Finally, with regard to children born out of wedlock, Article 1 of Interpretation 2 of the Marriage Law stipulates that if a party sues for dissolution of cohabitation, the people's court shall not accept it. However, if a party requests the dissolution of the cohabitation relationship, which belongs to "cohabitation of a spouse with another person" stipulated in Articles 3, 32 and 46 of the Marriage Law, the people's court shall accept and dissolve it according to law. The people's court shall accept a lawsuit brought by a party in connection with the dispute over the division of property or the upbringing of children during the period of cohabitation.

\section{B. Problems Exposed to Cohabitation Phenomenon}

\section{1) Personal relationship between cohabitants}

The two parties who live together without marriage cannot justify their cohabitation relationship in the public security department or issue some form of proof of relationship in the administrative department, and then a series of judicial interpretations are introduced, and disputes over cohabitation relations are gradually excluded from the scope of court acceptance. This practice of allowing unmarried cohabitation to be not regulated aggravates the problems and contradictions of the phenomenon of unmarried cohabitation. Even if the choice of non-marital cohabitation, the identification of the identity relationship between the two parties is a necessary step in resolving disputes, but the law has not given strong protection to the identity relationship of non-marital cohabitation.

In addition to the aforementioned partners in internal disputes need to be legally guaranteed their identity relationship. On the other hand, the absence of laws leads to the confusion of partners' external property relations. For the third party, it may be because they believe that they are the property community or do not know that they are the property community, resulting in unsafe creditor's rights and liabilities. Only by determining the cohabitation relationship can a third party make a comprehensive assessment of the property status of the other party.
The most important dispute resolution involved in identity relations is also reflected in inheritance and adoption. In non-marital cohabitation, the parties do not enjoy some rights based on emotional factors as "spouses" in marriage law and related laws, such as tort damages, visits, and comfort. And in a partnership that supports each other to the old, the inheritance of one partner, in accordance with the law, ruthlessly excludes an unmarried partner unless it is explicitly bequeathed or based on a negligible so-called moral compensation.

\section{2) Property relations}

Previously, because of the identity relationship, it mostly involves the external property relationship, where the property relationship mainly involves the internal property relationship between the partners. China's marriage law has a brief provision on the property of non-marital cohabitation, but there is no specific solution. What kind of common relationship does non-marital cohabitation refer to, and whether the immeasurable family labor should be taken into account when dividing property? There are no provisions in China's marriage law, which lead to the partners who pay more for family life, especially the family. Women's rights and interests in China are not effectively protected. The person who is more attached to this relationship will deviate from the principle of seeking perfection and pay more labor, undertake more obligations, suffer more exploitation, suffer more harm after the breakdown of the cohabitation relationship, and even fall into a difficult situation. But the law does not take these situations into deep consideration. As a result, women who engage in a lot of housework cannot get corresponding assistance after the dissolution of cohabitation relationship or after the death of the other party, and their economic situation has deteriorated seriously. This is nothing more than excluding the rights of non-marital cohabitants from the scope of legal protection, making the disadvantaged party a victim of the concept of pluralistic social and family autonomy. The ownership and use of property can be agreed upon between cohabiting parties. Where there is no agreement, it shall be handled in accordance with the common property. Regarding how to deal with it, the Marriage Law and its judicial interpretation do not provide for it. How to deal with the creditor's rights and debts formed during cohabitation for the purpose of joint production and living has not been specified.

In a word, China's marriage law not only excludes unmarried cohabitation from the scope of adjustment, especially the status relationship between unmarried cohabitants is not mentioned, but also provides for the treatment of property and children in the cohabitation relationship in a principled way, and even has no operability in its application. As a result, it is easy for people to choose non-marital cohabitation relationship, and it is extremely difficult to deal with disputes in non-marital cohabitation relationship. 


\section{RATIONALITY OF LEGAL REGULATIONS ON UNMARRIED COHABITATION}

\section{A. Benefiting the Protection of Vulnerable Groups}

People have the right to choose to live together without marriage and bypass the marriage system to form a family, but that does not mean that they have abandoned the legal protection of their legal rights. Although non-marital cohabitation can bring convenience and benefits to the parties concerned, if there is no legal guarantee, when the cohabitation relationship is in trouble, the vulnerable groups cannot seek relief if they pay more in the family. Only by giving the parties certain legal protection, can the status of the vulnerable in the cohabiting family be improved.

\section{B. Benefiting the Protection of Minor Children}

When the non-marital cohabitation relationship breaks down, children often suffer the greatest damage. Only longterm and stable family relationship can provide a good growth environment for children. Whether parents are married or cohabiting, parents and society have an inescapable legal and social responsibility for children. Therefore, only by perfecting the legal regulation of nonmarital cohabitation in China can the healthy growth of children born out of wedlock as well as children born in wedlock be guaranteed.

\section{CONCLUSION}

The phenomenon of non-marital cohabitation in China has become a spark of fire, and it is an irresistible trend of the times. Because the economic development has led to the transformation of social forms, and also affected people's lifestyle and traditional customs, its emergence has its inevitability and rationality, but the absence of law has led to the phenomenon cannot develop in a better direction. Choosing non-marital cohabitation is the freedom of contemporary people outside the law, but harmless freedom needs to be guaranteed by law, and once the problem of nonmarital cohabitation arises, the legal responsibility is to take the most reasonable way to solve it. In today's changing society, laws can be late, but they must not be absent.

\section{REFERENCES}

[1] Richard A. Posner, (trans.) Su Li. Sex and Rationality [M]. China University of Political Science and Law Press, 2002:74-76.

[2] Xia Yinlan. Research on Factual Marriage System [M]. Beijing: China Procuratorial Publishing House, 2001.

[3] Zhang Wenxia, Zhu Dongliang, Family Social Work [M]. Social Science Literature Publishing House, 2005:50-52.

[4] Qian Kai: Research on Legal Problems of Unmarried Cohabitation [D]. Doctoral Thesis of Law, Heilongjiang University, 2012.

[5] Chen Wei, Wang Wei. The Social Basis and System Conception of Establishing the Law of Unmarried Cohabitation in China. Gansu Social Sciences, 2008, 1.

[6] Yan Zhenyu. Causes of the Phenomenon of Urban Youth's Trial Marriage [J]. Contemporary Youth Research, 2006 (01): 44-47.

[7] Li Jiezhen. Legal Analysis of Cohabitation [J]. Journal of Yichun University, 2004 (05): 55-59.
[8] Kate Standley, (trans.) Qu Guangqing. Family Law [M]. China University of Political Science and Law Press, 2004:4-5. 